\title{
Follow-ON BIOLOGICS LEGISLATION: STRIKING A BALANCE BETWEEN INNOVATION AND AFFORDABILITY
}

\author{
Brian R. Bouggy*
}

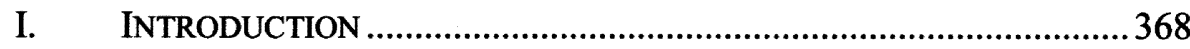

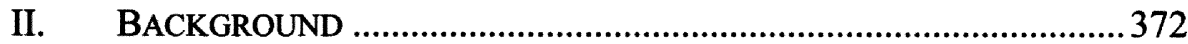

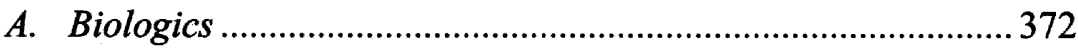

B. Health Care Expenditures Associated With Biologics............... 373

C. Competing Views regarding follow-on biologics....................... 374

D. Degrees of Exclusivity Granted to Innovators by Generic

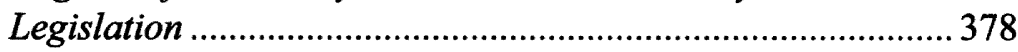

1. General Agreement on Tariffs and Trade (GATT)............ 380

2. The inhibitory effect of exclusivity provisions on

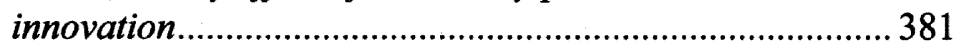

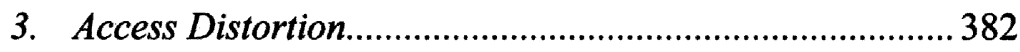

4. Hatch-Waxman Act-very limited exclusivity .................... 383

a. Potential savings associated with follow-on biologics.......................................................................... 383

$b \quad$ Hatch-Waxman's effect on follow-on biologics........... 384

E. Proposed Legislation .............................................................. 385

F. Shorter Exclusivity Periods May Actually Promote Innovation.

1. The Generic Pharmaceutical Association's Response to the Kotlikoff Study:

III. ANALYSIS: MODIFIED VERSION OF HATCH-WAXMAN APPLICABLE TO BIOLOGICS

A. Downfalls of proposed biogenerics bills...................................390

1. Cost/risk justification argument ......................................... 391

B. The Hatch-Waxman Act Should be Used as a Template for Generic Biologics Legislation.

C. Congress Should Assess the Arguments From These Two Inherently Biased Groups With a Focus on our Country's

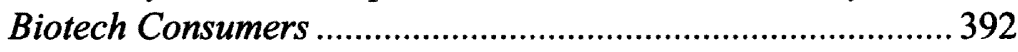

D. Biogeneric legislation as a catalyst for innovation. ..................394

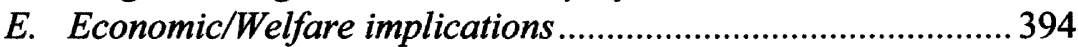

F. Exclusivity Provisions should allow for abbreviated periods of monopoly protection.

IV. CONCLUSION

* J.D., 2010, Indiana University School of Law - Indianapolis; B.S., 2007, Purdue University. 


\section{INTRODUCTION}

Recent scientific advances have resulted in new drugs and biological compounds which provide incredible life-saving potential, but come with a high price tag. ${ }^{1}$ Biologics, such as insulin and various cancer drugs, produced by extracting cellular proteins from animals, are changing the landscape of modern medicine. There exists remarkable potential for the discovery of new life-saving biologics, but the consumer too often bears the high cost of access to these revolutionary treatments. On average, biologics cost twenty-two times more per daily dose than chemical medications. ${ }^{2}$ Many biologic cancer treatments cost over $\$ 100,000$ a year. ${ }^{3}$ In the United States, spending on biologics has increased approximately fifteen to twenty percent annually, and exceeded $\$ 40$ billion in 2006 . $^{4}$ This Note will describe the barriers generic drug makers face when seeking approval of generic biologics. It will then assess the meritorious arguments of each side of this hotly debated issue. Finally, this Note will describe how a balance should be struck by lawmakers implementing new legislation to reduce rising medical costs by permitting the marketing of generic biologics, while maintaining these drugs' initial profitability, which will in turn continue to encourage innovation.

Biologics offer remarkable hope to those fortunate enough to gain access to them. Currently, compounds either being developed, being tested or on the market fight an array of conditions including arthritis, asthma, Alzheimer's disease, heart disease, Crohn's disease, various cancers, psoriasis, multiple sclerosis, Lou Gehrig's disease, and AIDS. ${ }^{5}$ These and other serious conditions treated by biologics account for a substantial portion of our nation's health problems, and a similarly substantial portion of health care spending. It is paramount that Congress implement new legislation in a manner which will promote innovation in this field and maximize the potential of these discoveries, while simultaneously making biologics more affordable to the general public.

1. Health Premium Hikes Tied to Costly Specialty Drugs, INs. J., Dec. 6, 2006, http://www.insurancejournal.com/news/east/2006/12/06/74723.htm (last visited Oct. 27, 2009).

2. Centers for Medicare and Medicaid, National Health Expenditures by Type of Service and Source of Funds (2008), http://www.cms.hhs.gov/nationalhealthexpenddata/ 03_nationalhealthaccountsprojected.asp (last visited Oct. 29, 2009).

3. Health Premium Hikes Tied to Costly Specialty Drugs, supra note 1.

4. Biologics Price Competition and Innovation Act of 2007, S. 1695, (as reported by S. Comm. on Health, Education, Labor and Pensions, Jun. 27, 2007) (recognizing this expenditure is being made primarily via third-party insurers or the government).

5. Pharmaceutical Research and Manufacturers of America (PhRMA), 2006 REPORT ON MEDICINES IN DEVELOPMENT - BIOTECHNOLOGY: 418 BioteChNOLOGY Medicines in Testing Promise to Bolster the Arsenal Against Disease 1 (2006), available at http://www.phrma.org/files/Biotech\%202006.pdf) (last visited Feb.12, 2009) [hereinafter "PHRMA REPORT"]. 
Until the recent passage of the Patient Protection and Affordable Care Act of 2009, Food and Drug Administration (FDA) regulations precluded the marketing of generic forms of biologics, often referred to interchangeably as biogenerics, biosimilars, or follow-on biologics. ${ }^{6}$ The justification for more stringent control of biologics than of chemical drugs lies in the theory that the complexity of biologics renders them less amenable to safe and effective duplication by generic manufacturers. ${ }^{7}$ As the scientific community learns more about biologics, however, it appears increasingly likely that many of these drugs can be safely and effectively duplicated.

At a time when medical costs are increasing at an alarming rate, Congress must consider all viable options for reducing this inefficient sector of our economy. Health care spending in the United States totaled \$2.4 trillion in 2008 and is projected to reach $\$ 3.1$ trillion in 2012, and \$4.3 trillion in $2017 .^{8}$ Health care costs accounted for approximately seventeen percent of our nation's gross domestic product (GDP) in 2008, and is projected to account for almost twenty percent of our GDP in 2017. 9 Prescription costs, particularly for extremely expensive biologics, are a major cause of rising medical expenditures. ${ }^{10}$ These expenses have a significant financial impact on individuals, employers, our government, and the world at large. Individuals faced with the life-threatening specter of cancer may be forced to deplete their finances to the point of bankruptcy in order to receive the treatment recommended by their oncologist. ${ }^{11}$

Harvard University researchers recently published findings which suggest the average out-of-pocket medical debt for individuals who filed for bankruptcy is $\$ 12,000$. $^{12}$ Approximately seventy-five percent of those filing for bankruptcy in the study had health insurance, and fifty percent of all bankruptcy filings were caused, at least in part, by medical expenses. ${ }^{13}$ The reality of this problem is put into sobering perspective by the fact that every thirty seconds in the United States someone files for bankruptcy in the af-

6. See Federal Food, Drug, and Cosmetic Act, 21 U.S.C. $\$ 301$ et seq. (1938).

7. Letter from John Taylor, Executive Vice President, Health, Biotechnology Industry Organization, to Secretary, Federal Trade Commission (Dec. 22, 2008) available at http://www.ftc.gov/os/comments/healthcarecompissues/537778-00042.pdf (last visited Mar. 6, 2010) [hereinafter "Letter from John Taylor"].

8. Sean Keehan, et al., Health Spending Projection Through 2017: The Baby Boom Generation is Coming to Medicare, 2 HEALTH AFFAIRS w145,w145 (2008), http://content. healthaffairs.org/cgi/content/abstract/27/2/w145 (last visited Mar. 15, 2010).

9. Id.

10. Wendy H. Schacht \& John R. Thomas, Follow-On Biologics: Intellectual Property and Innovation Issues, Congressional Research Service (Aug. 3, 2009), available at http://www.assets.opencrs.com/rpts/RL33901_20090803.pdf (last visited Mar. 6, 2010).

11. David U. Himmelstein, et al., Market Watch: Illness and Injury as Contributors to Bankruptcy, HEALTH AFFAIRS, Feb. 2, 2005, at W5-63,W5-64, http://content.healthaffairs. org/cgi/content/full/hlthaff.w5.63/DC1 (last visited Mar. 1, 2010).

12. Id. at W5-63.

13. Id. 
termath of a serious health problem. ${ }^{14}$ Therefore, establishing a regulatory pathway for generic biologics would help provide both economic and physical relief to those faced with catastrophic illness.

The more than $\mathbf{4 7}$ million Americans without health insurance are unlikely to have access to these drugs at all. ${ }^{15}$ Additionally, those with health insurance may not be covered for life-saving biologics. ${ }^{16}$ In response to the increase in expensive specialty drugs, many insurers are restructuring the system they use to determine which drugs they will pay for, and how much the patient is required to pay. Until recently, insurance companies classified drugs in three tiers based on cost and whether less expensive alternatives exist. ${ }^{17}$ Under this tiered copayment structure, patients would pay a fixed amount, " $\$ 5$ to $\$ 10$ per month for a generic medication (tier 1), $\$ 20$ to $\$ 30$ for a moderately priced brand-name drug (tier 2), and $\$ 50$ for a highpriced brand-name drug (tier 3)." 18 In response to the rising number of high-priced medications, many insurers have now implemented a fourth tier, under which patients must pay a fixed percentage (often 20 to $33 \%$ ) for all fourth tier drugs. ${ }^{19}$ With many biologic treatments costing well over $\$ 100,000$ annually, access to these drugs is often impractical for even insured middle-upper class families. ${ }^{20}$ Unfortunately, many are faced with the tragic choice between pursuing effective cancer treatment or providing for family expenses.

Employers providing health benefits feel the economic impact of highpriced biologics in the form of rapidly rising insurance premiums. United States employers saw their health insurance premiums rise by an alarming five percent in 2008 - two times the rate of inflation. ${ }^{21}$ As biologics become more prevalent, it is becoming increasingly expensive for employers to insure a large workforce. To maintain the viability of the employmentbased insurance scheme, it is necessary to cut medical costs. Failing to do so, when many employers are already cutting medical benefits due to the prohibitive cost of health care, could have catastrophic effects on our health

14. Elizabeth Warren, Sick \& Broke, WASH. Post, Feb. 9, 2005, at A23, available at $\mathrm{http}: / / \mathrm{www} . w a s h i n g t o n p o s t . c o m / w p-d y n / a r t i c l e s / A 9447-2005 F e b 8 . h t m l$ (last visited Mar. 1, 2010).

15. U.S. DEPT. OF COMMERCE, ECONOMICS AND Statistics AdMINISTRATION, U.S. CENSUS BUREAU REPORT: INCOME, POVERTY, AND HEALTH INSURANCE COVERAGE IN THE UNITED STATES: 200520 (2006), available at http://www.census.gov/prod/2006pubs/p60231.pdf (last visited Mar. 1, 2010) [hereinafter “CENSUS REPORT”].

16. Id.

17. Thomas H. Lee, M.D., and Ezekiel J. Emanuel, M.D., Ph.D., Tier 4 Drugs and the Fraying of the Social Compact, 359 N. ENGL. J. MED. 333, 333 (2008).

18. Id.

19. Id.

20. Health Premium Hikes Tied to Costly Specialty Drugs, supra note 1.

21. The Kaiser Family Foundation \& Health Research \& Education Trust, EMPLOYER HEALTH BENEFITS: 2008 ANNUAL SURVEY 1 (2008), available at http://ehbs.kff. org/ped/7790.pdf (last visited Mar. 1, 2010). 
care system. $^{22}$ Allowing follow-on biologics would be an effective method to provide relief to employers, and would reduce the likelihood of employers discontinuing health benefits.

The country's biggest insurer, the United States government, could also benefit from follow-on biologics. ${ }^{23}$ A Congressional Budget Office report released in December 2008 analyzes an abbreviated regulatory pathway for follow-on biologics as a potential measure to decrease federal health care expenditures. ${ }^{24}$ The Report estimates such a plan would save the Medicare and Medicaid programs $\$ 10.6$ billion between 2010 and $2019 .^{25}$

The benefits of a regulatory pathway for follow-on biologics in the United States would be realized worldwide. Biogeneric legislation in the United States could also aid our country's use of life-saving drugs to combat serious illness in third world countries, such as human immunodeficiency virus ("HIV") in many African nations. ${ }^{26}$ A majority of the antiretroviral drugs which have proven successful in treating HIV are biologics. $^{27}$ The availability of follow-on biologics would be invaluable to African nations in their fight against the AIDS epidemic.

A well-crafted abbreviated regulatory pathway for follow-on biologics would help alleviate the economic strain high-priced drugs place on domestic and international health care systems, while encouraging the discovery of new biologics through increased competition. ${ }^{28}$ The need for generic biologics has become so great that even brand name biotech lobbyists are beginning to acknowledge the need for a practical regulatory pathway for generic forms of their drugs. The Biotechnology Industry Organization ("BIO"), a lobbying group which represents the interests of name-brand biologics manufacturers, recently conceded the necessity of follow-on biologics legislation:

22. Bruce Japsen, Employers to Shrink Insurance Benefits, CHI. TRIB., Mar. 5, 2009, at 20.

23. CENSUS REPORT, supra note 15; Letter from John Taylor, supra note 7.

24. Congressional Budget Office, Budget Options Volume 1: Health Care 126 (2008), available at http://www.cbo.gov/ftpdocs/99xx/doc9925/12-18-HealthOptions.pdf (last visited Mar. 3, 2010).

25. Id. at 127 .

26. Arachu Castro \& Michael Westerhaus, How Do Intellectual Property Law and International Trade Agreements Affect Access to Antiretroviral Therapy?, 3 PLOS MED. $1230,1233-34$ (2006), available at $\mathrm{http}: / / \mathrm{www}$.plosmedicine.org/article/info\%3Adoi\%2F10. 1371\%2Fjournal.pmed.0030332 (last visited Mar. 3, 2010) (discussing United States policies addressing the need to increase treatment for HIV in the U.S. and in foreign countries).

27. Castro \& Westerhaus, supra note 26, at 1232.

28. See Laurence J. Kotlikoff, StimULATING INNOvation IN THE Biologics Industry: A BALANCED APPROACH TO MARKETING EXCLUSIVITY 1 (Teva USA Government Affairs) (2008) available at http://www.kotlikoff.net/sites/default/files/Kotlikoff_Innovation_in_Biologics21.pdf (last visited Mar. 6, 2010) (asserting that "competition, not protection, is the true source of innovation and ... overextending monopoly protection can be counterproductive" $I d$.). 
BIO strongly supports bipartisan efforts to pass legislation to create a pathway for approval of follow-on biologics this year. This issue is too important to subject to special-interest politics and misinformation campaigns. Patients, employers, and public programs such as Medicare have waited long enough. The time for responsible follow-on biologics legislation is now. ${ }^{29}$

This Note will provide background information regarding biologics and their importance in our health care system. This Note will then assess the position of those groups with the greatest interest in follow-on biologics legislation. Finally, this Note will analyze how Congress should seek to strike a balance between innovation and competition in order to make affordable biologics a reality. The benefits to be gained are too great, and the consequences of inaction are too dire, for further delay in the passage of effective follow-on biologics legislation.

\section{BACKGROUND}

\section{A. Biologics}

The term "biologics" generally refers to a class of medications which are derived from living organisms using recombinant DNA technology. ${ }^{30}$ Although biologics are used to treat a wide range of medical conditions, they are most prevalent in the areas of immunological disease, cancer, cardiology, gastroenterology, neurology, and others. ${ }^{31}$ The high price tag these drugs carry with them, however, present serious budgetary and regulatory concerns, particularly because they are often used for long-term treatment of chronic diseases. ${ }^{32}$ For example, Cerezyme, a biologic used to treat Gaucher's disease, costs approximately $\$ 200,000$ per patient annually. ${ }^{33}$

Some of the most widely prescribed biologics (and their main use) include Bristol-Myers Squibb's Orencia (rheumatoid arthritis treatment),

29. Press Release, Biotechnology Industry Organization, Setting the Record Straight: Generic Drug Industry Lobby 'Flat Out Wrong' About BIO Position on Follow-On Biologics (April 1, 2008), available at http://bio.org/news/pressreleases/newsitem.asp?id=2008_0401_02\&p=yes (last visited Oct. 28, 2009) [hereinafter "BIO Press Release I"].

30. See Press Release, Generic Pharmaceutical Association, GPhA Statement on BIO's Flawed Data Exclusivity White Paper (January 30, 2009), available at http:// www.gphaonline.org/print/media/press-releases/2009/gpha-statement-bios-flawed-data-

exclusivity-white-paper (last visited Oct. 28, 2009) [hereinafter "GPhA Press Release I"]; BIO Press Release I, supra note 29.

31. PHRMA REPORT, supra note 5, at 1.

32. Thomas Morrow, M.D., Five Steps to Managing Biologics, 2004 BIOTECHNOLOGY HeAlthCARE 20, 20-26.

33. Health Premium Hikes Tied to Costly Specialty Drugs, supra note 1. 
Amgen's Epogen (treatment of anemia arising from cancer chemotherapy), Genentech's Herceptin (breast cancer treatment), Human Insulin (diabetes management), and Human Growth Hormone (various uses). ${ }^{34}$ The prevalence of these drugs, and the great potential associated with them, illustrates the urgency for comprehensive legislation to ensure affordability and encourage innovation.

\section{B. Health Care Expenditures Associated With Biologics}

Increasing in both number and effectiveness, prescription drugs play a significant role in our Nation's $\$ 2$ trillion health care system. ${ }^{35}$ Currently, prescription drug expenditures comprise one-tenth of total healthcare expenditures nationwide, compared with one-twentieth of health care expenditures in $1980 .^{36}$ Biologics are being used to treat more than 800 million patients worldwide. ${ }^{37}$ According to a recent study, biologic sales worldwide increased twelve and one-half percent in 2007, amounting to more than $\$ 75$ billion, which is an increase twice as much as in chemical drug sales. $^{38}$ Spending on biologics is expected to reach $\$ 90$ billion by $2009 .^{39}$ The Centers for Medicare and Medicaid Services ("CMS"), states that the top two anemia drugs, both biologics, accounted for 17 percent of all Medicare Part B carrier drug spending in fiscal year 2005, and two other biologics for rheumatoid arthritis and cancer accounted for an additional 13 percent of all carrier spending. 40

Due to tremendous advances in medicine, life expectancy in America has increased greatly, resulting in a life expectancy in the upper 70's for

34. PHRMA REPORT, supra note 5, at 5, 6, 12, 23, and 26.

35. Centers for Medicare and Medicaid Services, National Health Expenditures Accounts: Definitions, Sources and Methods 23 (2008), available at http://www. cms.hhs.gov/NationalHealthExpendData/downloads/dsm-08.pdf (last visited Mar. 4, 2010).

36. Id.

37. Biotechnology Industry Organization, Milestones 2006: Health, http://www.bio. org/speeches/pubs/milestone06/health.asp (last visited Jan. 5, 2009).

38. Press Release, IMS Health, IMS Health Reports Global Biotech Sales Grew 12.5 Percent in 2007, Exceeding $\$ 75$ Billion (June 17, 2008), available at http://www.imshealth. com (Select "Press Room" in top right corner, then select "Press Releases" in column to left, then select "2008" from drop-down menu for year, then scroll down and select "IMS Health Reports Global Biotech Sales Grew 12.5 Percent in 2007, Exceeding \$75 Billion” hyperlink) (last visited Mar. 4, 2010).

39. The Generic Drug Maze: Speeding Access to Affordable, Life Saving Drugs: Hearing on S.2300 Before the S. Special Comm. on Aging, 109th Cong. 11 (2006) (statement of Mark Merritt, President and Chief Executive Officer, Pharmaceutical Care Management Association), available at http://www.pcmanet.org/newsroom/July\%202006/7-20-2002/PCMA\%20Final\%20Senate\% 20Aging\%207\%2020\%2006.pdf (last visited Jan. 15, 2009).

40. Payment for Medicare Part B: Hearing Before H. Subcomm. on Health of the H. Comm. on Ways and Means, 109th Cong. (2006) (statement of Herb Kuhn, Director, CMM), available at http://www.cms.hhs.gov/apps/media/press/release.asp?Counter=1904 (last visited Mar. 4, 2010). 
Americans. ${ }^{41}$ Because this increase in life expectancy is often made possible through the administration of biologic drugs over an extended period of time, the elderly population faces skyrocketing increases in health expenditures. Legislation allowing for an abbreviated regulatory pathway for follow-on biologics should be a priority for the new Administration in order to alleviate the burdens created by the prohibitive costs of these drugs.

Experts predict that in coming years half of all newly approved drugs will be biologics. ${ }^{42}$ This increase in market share will serve to exacerbate the existing financial problems stemming from these costly drugs. Each new safe and effective biologic is a victory for modern medicine, but the potential of these drugs will never be realized unless they are made relatively affordable. ${ }^{43}$ Absent calculated measures by Congress to decrease the cost of biologics, their life-saving capabilities will be available only to those fortunate enough to afford the high cost, or those with exceptional health benefits.

\section{Competing Views regarding follow-on biologics}

The debate regarding whether generic biologics should be approved by FDA centers around two main areas of contention: 1) whether it is feasible for generic drug companies to replicate name brand biologics safely and effectively; and 2) whether the introduction of generic biologics into the marketplace will destroy name brand drug companies' incentive to innovate by rendering the drugs unprofitable. ${ }^{44}$ Not surprisingly, viewpoints of interested parties on the viability of follow-on biologics, and the effect they would have on our nation's health care system, vary greatly. ${ }^{45}$

Generic versions of chemical drugs, manufactured using precise chemical formulas, reach market through the abbreviated regulatory pathway provided by the Drug Price Competition and Patent Term Restoration Act, more commonly referred to as the Hatch-Waxman Act. ${ }^{46}$ The generic

41. Arialdi M. Miniño, Melonie P. Heron \& Betty L. Smith, Deaths: Preliminary Data for 2004, NAT'L VITAL STAT. REP., June 28, 2006, at 3, available at http://www.cdc.gov/ nchs/data/nvsr/nvsr54/nvsr54_19.pdf (last visited Mar. 6, 2010).

42. Schacht, supra note 10, at 6-8 (highlighting the efficient production of and growing need for biologics); Gina Kolata, Co-Payments Go Way UP for Drugs with High Prices, N.Y. TimES, April 14, 2008 (discussing the fact that both Medicare and private insurers now offer Tier 4 plans).

43. See e.g., Kolata, supra note 42.

44. See Kotlikoff, supra note 28, at 4; See also e.g., GPhA Press Release I, supra note 30; BIO Press Release I, supra note 29.

45. Compare BIO Press Release I, supra note 29 (supporting the idea that legislation creating a regulatory pathway for follow-on biologics should require fourteen years of data exclusivity), with GPhA Press Release I, supra note 30 (contending that exclusivity does not promote a balance between competition and innovation).

46. Drug Price Competition and Patent Term Restoration Act, Pub. L. No. 98-417, 98 Stat. 1585 (1984). 
legislation's Congressional sponsors, Senator Orrin Hatch and Representative Henry Waxman, remain strong advocates of generic drugs. ${ }^{47}$ Under the Hatch-Waxman regulatory structure, generic drug companies are able to forgo the extensive human clinical trials brand-name drug companies must undertake to show that their drug is safe and effective. ${ }^{48}$ A generic drug company must establish that its drug it is "pharmaceutically equivalent" that is, it contains the same active ingredient, in the same amount and dosage. ${ }^{49}$ As part of the approval process, a generic drug company must also establish its drugs' "bioequivalence" by showing that it absorbs into a patient's bloodstream at a similar rate as the brand name drug. ${ }^{50}$ Provided the generic company satisfies these, and other minor requirements, it is not required to undertake clinical studies in order to gain FDA approval for their drug. 51

The savings a generic drug company enjoys under the Hatch-Waxman abbreviated approval process account for the savings consumers enjoy when purchasing generic drugs. There is currently no abbreviated regulatory pathway for follow-on biologics. ${ }^{52}$ Consumers are still waiting for affordable versions of these drugs.

The Biotechnology Industry Organization (BIO), which represents the interests of leading biotechnology companies such as Amgen and Genentech, contends that the complexity of biologics may preclude their safe duplication by generic drug companies. ${ }^{53}$ It is the general consensus among researchers that "[b]iologics differ significantly from traditional smallmolecule pharmaceuticals in their size, structural complexity, and method of manufacture." 54 Further, BIO argues that approval of follow-on biologics would destroy the incentive to develop lifesaving drugs, as the loss in profits to generic manufacturers would render it impractical to fund necessary research. 55

Conversely, the Generic Pharmaceutical Association asserts that they are capable of safely duplicating biologics, and that the resultant savings are

47. Id.

48. Id.

49. Id.

50. Id.

51. $I d$.

52. See U.S. Food \& Drug Admin, Center for Drug Evaluation \& Research, Frequently Asked Questions About Therapeutic Biological Products, available at $\mathrm{http} / / \mathrm{www} / \mathrm{fda} / \mathrm{gov} /$ cder/biologics/qa.htm (last visited Mar. 6, 2010).

53. Press Release, Biotechnology Industry Organization, Congress Must Protect Patient Safety and Promote Innovation in Considering Follow-on Biologics Pathway (Mar. 8, 2007), available at http://bio.org/news/pressreleases/newsitem.asp?id=2007_0308_01 (last visited Mar. 6, 2010) [hereinafter "BIO Press Release II"].

54. Schacht, supra note 10, at Summary.

55. Press Release, Biotechnology Industry Organization, BIO Calls For 14 Years of Data Exclusivity in Any Follow-On Biologics Legislation (May 3, 2007), available at $\mathrm{http} / / / \mathrm{bio}$. org/news/pressreleases/newsitem.asp?id=2007_0503_01 (last visited Mar. 6, 2010) [hereinafter "BIO Press Release III"]. 
so significant that they should compel the enactment of legislation approving follow-on biologics. 56 Some experts in this field contend that "different kinds of biologics vary considerably in their size and structure, and ... existing Hatch-Waxman mechanisms are appropriately applied to many biologics.",57

The debate between these two powerful lobbying groups has grown more contentious over the past year, with accusations of misleading tactics. $^{58}$ In an April 1, 2008 press release, BIO condemned the Generic Drug Industry's lobbying groups for engaging in what it considered a gross mischaracterization of BIO's position on follow-on biologics. BIO expressed its disappointment that, instead of engaging in a healthy discussion "based on facts and credible data, the generic drug industry's lobby keeps pushing misinformation to the news media, policymakers, and others that is flat out wrong."59

BIO recently expressed their concerns regarding follow-on biologics through comments submitted to the Federal Trade Commission. ${ }^{60}$ In their comments, BIO first expresses skepticism regarding the extent to which follow-on biologics are interchangeable with their brand-name predecessors. ${ }^{61}$ It contends that "assumptions regarding... interchangeability of [follow-on biologics] in the foreseeable future are not science-based."62 Further, BIO argues that allowing for "[i]nterchangeability will not necessarily provide greater economic benefit." 63 The lobbying group's stance regarding data exclusivity remains that a "period of 14 years is necessary to maintain effective market protection for innovator biologics, and thus sufficient incentives for innovation." ${ }^{\circ 4}$ Notwithstanding these serious reservations regarding follow-on biologics, BIO contends that legislation addressing follow-on biologics would be appropriate if it allows for proper "incentives for continued development of next-generation products." primary incentive for innovation that BIO seeks is assurance that itwill be provided what it deems as sufficiently lengthy data exclusivity protection fourteen years. ${ }^{66}$ This protection, the organization argues, is "important for advancement of medical treatment and would not prevent FOB market entry.", 67

56. GPhA Press Release I, supra note 30.

57. Schacht, supra note 10, at Summary.

58. See e.g., BIO Press Release I, supra note 29.

59. Id.

60. Letter from John Taylor, supra note 7.

61. Id.

62. Id.

63. Id.

64. Id.

65. Letter from John Taylor, supra note 7.

66. Id.

67. Id. 
It would be a significant victory for brand name drug manufacturers if follow-on biologics legislation were to include provisions precluding biologics from the presumed substitutability and interchangeability chemical generic drugs enjoy under the Hatch-Waxman Act. ${ }^{68}$ BIO argues that recognition of substitutability and interchangeability for biologics would undermine the physician's discretion in prescribing which biologic to take, because "[n]o two biologics are identical and some differences could have clinical implications that are not known at the time of approval." ${ }^{\circ 9}$ Concurring with BIO on this issue, the American Medical Association passed a resolution committing to "work with the U.S. Food and Drug Administration and other scientific and clinical organizations to ensure that any legislation that establishes an approval pathway for follow-on biological products prohibits the automatic substitution of biosimilar medicines without the consent of the patient's treating physician.",70

BIO highlights other countries' approach to substitutability and interchangeability in their treatment of follow-on biologics. ${ }^{71}$ For example, United Kingdom government officials have stated, "When prescribing biological products, it is good practice to use the brand name. This will ensure that automatic substitution of a biosimilar product does not occur when the medicine is dispensed by the pharmacist." ${ }^{, 72}$ French authorities have also noted, "a systematic and uncontrolled substitution, based on the prescription of the international common denomination of the active substance, does not appear reasonable at this time... physicians should be involved in decisions to substitute any BMP [biological medicinal product]." 73

BIO further asserts that a finding of interchangeability will not necessarily result in greater savings to consumers. ${ }^{74}$ Other factors, they argue, may have a greater effect on the extent to which consumers actually save:

The degree of competition and potential cost savings arising from a follow-on biologics approval pathway is likely to be heavily dependent on numerous factors beyond the question of interchangeability, including number of market entrants, product quality, cost of production, price discounting, market penetration, po-

68. Drug Price Competition and Patent Term Restoration Act, Pub. L. No. 98-417, 98 Stat. 1585 (1984); Letter from John Taylor, supra note $7 .$.

69. Letter from John Taylor, supra note 7.

70. Id.

71. $I d$.

72. Id. (citing MHRA Drug Safety Update: Vol. 1, Issue 7 (Feb. 2008), available at http://www.mhra.gov.uk/Publications/Safetyguidance/Drug SafetyUpdate/CON2033917):

73. Id. (citing Pavlovic et al; Similar Biological Medicinal Products Containing Recombinant Human Growth Hormone: European Regulation; Hormone Research; 2008; 69; 14-21).

74. Biotechnology Industry Organization, supra note 8. 
tential market size for any given product, etc. Indeed, a finding of interchangeability may in fact lead to lower savings to consumers, depending on its impact on these other critical factors. BIO therefore believes it would [be] imprudent for the FTC to rely on erroneous scientific and economic assumptions - i.e., that interchangeability is likely and would necessarily lead to greater cost savings - in crafting any public policy recommendations relating to a FOBs regime. ${ }^{75}$

\section{Degrees of Exclusivity Granted to Innovators by Generic Legislation}

Laws granting generic manufacturers the right to duplicate brand name drugs typically allow the original manufacturer a term of exclusivity, during which the original manufacturer is able to profit from its innovation without having to compete with less expensive generics. ${ }^{76}$ Exclusivity is granted in two forms - data exclusivity and approval exclusivity (market exclusivity). ${ }^{77}$ Data exclusivity in this context typically refers to statutory prohibition of the approval for a generic product which uses an innovator product as its reference product. $^{78}$

A data exclusivity period is the time during which a potential generic supplier of a given drug is barred from submitting an Abbreviated New Drug Application ("ANDA"). ${ }^{79}$ An ANDA allows generic companies to save the time and expense of the extensive clinical trials required for the approval of an entirely new drug. ${ }^{80}$ During a data exclusivity period, the FDA may not use the innovator's safety and effectiveness data as a basis for approving a generic alternative. ${ }^{81}$

Approval exclusivity, often termed market exclusivity, refers to the period during which a drug supplier is free to file their ANDA using the brand company's safety and effectiveness data, but cannot receive approval. ${ }^{82}$ Initially, the distinction between these two types of approval seems trivial being barred from filing for approval under data exclusivity, and being per-

75. Id.

76. Drug Price Competition and Patent Term Restoration Act, Pub. L. No. 98-417 (1984), 98 Stat. 1585 (1984).

77. Schacht, supra note 10, at 12-13; Drug Price Competition and Patent Term Restoration Act, Pub. L. No. 98-417 (1984), 98 Stat. 1585 (1984).

78. Schacht, supra note 10, at 13; Drug Price Competition and Patent Term Restoration Act, Pub. L. No. 98-417 (1984), 98 Stat. 1585 (1984).

79. U.S. Food and Drug Admin., Abbreviated Drug Application (ANDA): Generics, http://www.fda.gov/Drugs/DevelopmentApprovalProcess/HowDrugsareDevelopedandAppro ved/ApprovalApplications/AbbreviatedNewDrugApplicationANDAGenerics/default.htm (last visited Jan. 13, 2009).

80. Id.

81. Id.

82. Kotlikoff, supra note 28 , at 6. 
mitted to file but precluded from approval under approval exclusivity. However, the two types of exclusivity have a very practical effect on the degree of monopoly they grant. ${ }^{83}$. Generic drug suppliers are only able to challenge the patents of brand name counterparts if they have filed for FDA approval. ${ }^{84}$ Under data exclusivity, even patents which would be found invalid under judicial review are immune to competitors' challenges. ${ }^{85}$

BIO consistently contends that fourteen years of data exclusivity, essentially complete monopoly, is necessary in order to maintain the incentive to innovate. ${ }^{86}$ "Biotechnology companies must have some certainty that they can protect their investment in the development of new breakthrough therapies for a substantial period of time in order to secure the necessary resources from venture capital firms and other funding sources." 87 BIO further expresses its concern that an "uncertain "similarity" standard with respect to biologics will create "a greater potential for biologic patents to be designed around, particularly given some of the available case law involving the scope of biologic patents." ${ }^{, 88}$ BIO claims these uncertain standards will result in difficulty justifying commitment of the resources necessary to bring a biologic to market "[b]ecause FOBs will not have to comply with rigorous 'sameness' standards for traditional pharmaceutical generics...[Thus,] biologics patent portfolios will not provide the same level of certainty for innovators and investors as patents do for traditional pharmaceuticals against premature generic entry., 89

To illustrate the validity of their stance on data exclusivity, BIO cites a 1990 case involving two leading biotechnology companies. ${ }^{90}$ There, Genentech was sued by Hormone Research Foundation in a dispute regarding its recombinant human growth hormone product. ${ }^{91}$ The accused product, manufactured by Genentech, differed from Hormone Research Foundation's patented human growth hormone product by only two amino acids. Notwithstanding the near identical nature of the products, the U.S. Court of Appeals for the Federal Circuit found that Hormone Research Foundation's patent did not cover the accused product. ${ }^{92}$

BIO's statement contains a narrow, and perhaps even misleading view, of the Genentech decision. The Court implies that if it were not for limiting language in Hormone Research Foundation's patent, the Genentech

83. See e.g., Schacht, supra note 10, at 13-14.

84. Id. at 14 .

85. $I d$.

86. Letter from John Taylor, supra note 7.

87. Id.

88. Id.

89. Id.

90. Letter from John Taylor, supra note 7 (citing Hormone Res. Found. v. Genentech, 904 F.2d 1558 (Fed. Cir. 1990)).

91. Letter from John Taylor, supra note 7.

92. Hormone Res. Found. v. Genentech, 904 F.2d 1558 (Fed. Cir. 1990). 
product may have been found to be infringing based on the doctrine of equivalents. ${ }^{93}$ Concern that biologics manufacturers may have over the stability of their patents should be mitigated by the doctrine of equivalents, an equitable doctrine intended "in situations where there is no literal infringement but liability is nevertheless appropriate[,] to prevent what is in essence a pirating of the patentee's invention." 94 Under this doctrine, a product may infringe an existing patent if it performs "substantially the same function in substantially the same way to give substantially the same result." 95 So, while brand name manufacturers' concern regarding the similarity requirement for generic biologics is not unreasonable, it may be overstated.

It is important to note that exclusivity rights are entirely separate from patent protection. ${ }^{96}$ These types of protection are not on the same timetable - exclusivity periods begin with FDA approval of the brand drug, whereas patent protection begins after the new discovery is made and a patent application is approved by the United States Patent and Trademark Office. ${ }^{97}$ "The upshot here is that if the total period of exclusivity exceeds the amount of patent protection left at the time of FDA NDA approval, monopoly protection will be expanded by the number of years that exclusivity exceeds remaining patent life." 98

\section{General Agreement on Tariffs and Trade (GATT)}

Some legislation allows for innovators to evergreen its drugs. Evergreening refers to the process whereby patent holders use the time afforded by initial monopoly protection to make minor modifications to the biologics formulation in order to garner extended periods of exclusivity. ${ }^{99}$ When pursuing this strategy, innovators make changes which are significant enough to lengthen statutory exclusivity, but not so significant that they affect a drug's function or require extensive investment. Some trivial modifications typically made in an effort to evergreen drugs include the following:

changing the medication strength of pills (e.g., changing the pills from $.10 \mathrm{mg}$ to $.15 \mathrm{mg}$ ), changing the form of medication (e.g., switching from pill to cap-

93. Genentech, 904 F.2d at 1564.

94. Loctite Corp v. Ultra-Seal Ltd., 781 F.2d 861, 870 (Fed. Cir. 1985).

95. Id.

96. Drug Price Competition and Patent Term Restoration Act, Pub. L. No. 98-417 (1984), 98 Stat. 1585 (1984).

97. Id.

98. Kotlikoff, supra note 28 , at 6.

99. Id. at 9. 
sule), modifying the method of delivery (e.g., from injection to inhalation), expanding indications (applying the medicine to additional conditions), pegylation (which has the effect of reducing doses per time period via time-release mechanisms), and glycosolation (adding sugar molecules to the medication). ${ }^{100}$

The existence of these provisions, as well as the varying degrees of latitude they give innovators to extend their monopoly, is important when assessing the fairness of proposed legislation.

\section{The inhibitory effect of exclusivity provisions on innovation}

Innovators build on others' achievements in making new discoveries. Sir Isaac Newton referred to this age-old process, stating "[i]f I have seen further it is by standing on ye shoulders of Giants." 101 Any policy which effectively lengthens the time between innovations may result in decreased innovation over time. Decreased innovation in general has a profound effect on our economy, but decreased innovation of life-saving drugs reaches much further than the bottom line - it negatively impacts our health. Once a drug company has received approval for a blockbuster biologic, the company is typically less inclined to promote discovery of new drugs to the same extent it had prior to approval of that drug. "[Y]esterday's inventors are much less likely to be either today's innovators or tomorrow's."102 Once an innovator has made a discovery, he or she is faced with different incentives than those that may have prompted the discovery. The brand company diverts resources from innovation towards building and sustaining the profitability of its new discovery.

Consider for example, GenetiCo, a hypothetical Biologics manufacturer which spends millions of dollars to make an initial discovery of a protein-based compound which can be developed into a lifesaving cancer drug. After the discovery is made, GenetiCo's main goals include protecting this intellectual property, developing the drug, conducting clinical trials, gaining FDA approval for the drug; and finally manufacturing, marketing, and selling the drug. These goals do not coincide with the devotion of significant resources towards building on the discovery. If GenetiCo were to build on the discovery and essentially produce a better version of the current prod-

100. Id.

101. Letter from Sir Isaac Newton to Robert Hooke (Feb. 15, 1676). This letter was originally dated Feb. 5, 1675 using the Julian calendar with March 25th rather than January 1st as New Years Day. According to Gregorian theorists, the original date is equivalent to Feb. 15, 1676.

102. Kotlikoff, supra note 28 , at 4. 
uct, it would be diminishing much of the value of the initial invention. ${ }^{103}$

Many economists have concurred with Nobel Laureate Kenneth Arrow's contention that "the incentive to invent is less under monopolistic than under competitive conditions." ${ }^{104}$ Monopolists are less likely to innovate for a simple, though not necessarily obvious reason: if a company introduces an improved version of their existing product into the market they diminish their own revenue on their existing product. So long as a particular product is the only option for consumers, brand companies have no incentive to expend resources in an effort to improve their own product. As expiration of the monopoly approaches and the prospect of competition resurfaces, the wheels of innovation begin to churn again as the original innovator and hopeful competitors strive to produce the superior version of a product.

Of course, brand name drug companies need to be provided assurance that they will not only be able to recoup their investment in a given drug, but that the drug will be profitable. When these companies are afforded monopolies for time periods beyond what is necessary, however, the sacrifice in innovation and increased cost become more difficult to justify. Appropriate legislation will limit monopoly protection for biologics manufacturers to the length necessary to maintain the incentive to discover new drugs.

\section{Access Distortion}

The high price of biologics, coupled with the increasing number of uninsured and underinsured Americans, results in distorted access: those fortunate enough to have access to these drugs may not have the greatest need. $^{105}$ Aside from the obvious equity issues associated with this access distortion, efficiency concerns exist as well.

Markets in which some people face one set of prices for goods and services and other people face another set are inefficient for a simple reason - there are beneficial economic trades between the two sets of people that are not occurring

Concern about these efficiency costs explains why we

103. Id. at 4-5 (discussing mechanisms by which a biologics manufacturer prolongs its monopoly).

104. Kenneth J. Arrow, Economic Welfare and the Allocation of Resources for Invention (Rand Corp. Working Paper No. P-1856-RC, 1959).

105. Kotlikoff, supra note 28 , at 5. 
restrict monopolies, why we have patent limits, why we have free domestic trade, and why we form free trade agreements. ${ }^{106}$

Excessively lengthy protection monopolies enjoyed by name-brand biologics manufacturers result in decreased competition and in inefficient delivery of biologics to patients.

\section{Hatch-Waxman Act-very limited exclusivity}

Generic drugs are "identical, or bioequivalent to a brand-name drug in dosage form, safety, strength, route of administration, quality, performance characteristics, and intended use."107

\section{a. Potential savings associated with follow-on biologics.}

Proponents of lengthy exclusivity provisions assert that such provisions are essential to ensure profitability as an incentive to innovate. ${ }^{108}$ Conversely, some economists contend that lengthy exclusivity periods pose a serious threat to innovation. ${ }^{109}$ The latter of these views militates in favor of applying a modified version of the Hatch-Waxman Act, with its limited exclusivity, to promote biologic competition and innovation. ${ }^{110}$

"[T]he effects of Waxman-Hatch and GATT on [effective patent life] have been modest to date." 111 While the Hatch-Waxman Act does grant data and approval exclusivity for chemical-based drugs, this exclusivity is very limited compared to the provisions in many of the proposed biogeneric bills before Congress. ${ }^{112}$

Instead of the combined data plus approval exclusivity periods of twelve years (four data plus eight approval) years proposed in the Kennedy bill and fourteen years (twelve data and two approval) proposed in both the Eshoo-Barton and Inslee follow-on

106. Id.

107. U.S. Food and Drug Admin., Generic Drugs: Questions and Answers, http://www.fda.gov/drugs/resroucesforyour/consumers/questionsanswers/ucm 100100 .htm (last visited Oct. 21, 2009).

108. Drug Price Competition and Patent Term Restoration Act, Pub. L. No. 98-417 (1984), 98 Stat. 1585 (1984).

109. Kotlikoff, supra note 28, at 4.

110. See generally Drug Price Competition and Patent Term Restoration Act, Pub. L. No. $98-417,98$ Stat. 1585 (1984).

111. Henry G. Grabowski and John M. Vernon, Effective Patent Life in Pharmaceuticals, 19 INT'L J. TECH. MGMT. 98, 116 (2000).

112. Drug Price Competition and Patent Term Restoration Act, Pub. L. No. 98-417 (1984), 98 Stat. 1585 (1984). 
biologics bills, Hatch-Waxman offers five years of exclusivity generally, with four years of data exclusivity followed by one year of approval exclusivity if an applicant files a patent challenge in the fourth year. The Waxman follow-on biologics bill does not address data or approval exclusivity whatsoever. ${ }^{113}$

"The Hatch-Waxman Act also provides for patent restoration; the Act restores to a new chemical entity's patent life half of the time spent in clinical testing and all of the time spent securing FDA approval, up to a maximum of five years." A result of Hatch-Waxman's patent restoration provision is that the exclusivity provision is not likely to extend the total length of monopoly protection. ${ }^{15}$ The exclusivity provision, however, does serve to delay competitors' ability to contest innovators' patents by at least four years. ${ }^{116}$ The Hatch-Waxman Act has saved Americans billions of dollars in prescription drug expenses. ${ }^{117}$ Generic drugs provide safe and effective alternatives to their name brand counterparts, and often cost eighty percent less. $^{118}$

\section{b. Hatch-Waxman's effect on follow-on biologics}

There is one provision of the Hatch-Waxman Act, patent-term restoration, which currently applies to biologics as well as chemical drugs. ${ }^{119} \mathrm{Un}$ fortunately, this provision does not yet have any substantive force because there is currently no regulatory pathway for follow-on biologics to receive FDA approval. ${ }^{120}$ Since none of the proposed bills ${ }^{121}$ would affect this portion of the Hatch-Waxman Act, brand name drug companies would still receive significant protection of their patents through "four legislated types of monopoly protection - GATT, data exclusivity, approval exclusivity, and patent restoration. Each of these protections can impact the total length of monopoly protection depending on the particular circumstances involved. Under the Waxman bill, brand biologics would enjoy GATT and patent res-

113. Id.

114. Kotlikoff, supra note 28 , at 6.

115. See e.g., Grabowski and Vernon, supra note 111 , at 116 (stating that the HatchWaxman Act's effect on patent life has been "modest").

116. Drug Price Competition and Patent Term Restoration Act, Pub. L. No. 98-417 (1984), 98 Stat. 1585 (1984).

117. Alan J. Morrison, Biosimilars in the United States: A Brief Look at Where We Are and the Road Ahead, 26 BIOTECHNOLOGY L. REP. 463, 464 (2007) (citation omitted).

118. Id.

119. Drug Price Competition and Patent Term Restoration Act, Pub. L. No. 98-417 (1984), 98 Stat. 1585 (1984).

120. Id.

121. See e.g., Biologics Price Competition and Innovation Act of 2007, S. 1695, 110th Cong. (2007). 
toration protections." $" 122$

Three of the four biogeneric bills entail expansion of monopoly protection for biologics. ${ }^{123}$ Because new innovators rely on pre-existing scientific advances, the extension of monopoly protection has an exponential deleterious effect. For example, increasing monopoly protection from twenty to twenty-five years results in a twenty-five percent delay in the onset of the next innovation. ${ }^{124}$ In this case, the second innovation arrives five years late, the third 10 years late, the fourth 15 years late, the third 10 years late, the fourth 15 years late, etc. Over the course of a century, the country experiences not five innovations, but four."125 The decision to permanently extend monopoly protection has far greater consequences as time progresses, causing a greater decrease in innovation with each successive generation.

\section{E. Proposed Legislation}

All of the proposed legislation purports to allow for expenditure relief for the public while protecting the innovator's interests. ${ }^{126}$ These abbreviated regulatory procedures would allow the manufacturers of follow-on biologics "to sell the competing version at a discounted price by avoiding the substantial research and development expenses incurred by the brandname company to bring an innovator biological product to market, including costs associated with large, clinical trials necessary to demonstrate safety and effectiveness of the treatment in humans."127

The bipartisan Biologics Price Competition and Innovation Act of 2007, introduced by Senator Ted Kennedy (D, Mass.), would provide innovators twelve years of exclusivity and allow interchangeability upon the satisfaction of certain requirements. ${ }^{128}$ Once a drug is classified as interchangeable, a generic drug can be substituted for the original without physician approval. ${ }^{129}$. In June 2008, the Congressional Budget Office released findings that reflected this bill would save an estimated $\$ 25.2$ billion in biologic drug spending over ten years. In its report, the CBO estimates that:

122. Kotlikoff, supra note 28 , at 6-7.

123. Id. at 7 .

124. Id.

125. Id.

126. See generally, Pathway for Biosimilars Act, H.R. 5629, 110 th Cong. (2008).

127. Congressional Budget Office, Cost Estimate: S. 1695 - Biologics Price COMPETITION AND INNOVATION ACT OF 20074 (2008), available at http://www.cbo.gov/ ftpdocs/94xx/doc 9496/s1695.pdf (last visited Mar. 7, 2010) [hereinafter "CBO CosT ESTIMATE"].

128. Biologics Price Competition and Innovation Act of 2007, S.1695, 110th Cong. §7(A) (2007).

129. S. 1695. 
- Enacting S. 1695 would reduce total expenditures on biologics in the United States by $\$ 0.2$ billion over the 2009-2013 period and by about $\$ 25$ billion over the 2009-2018 period. (Over that 10-year period, such savings would equal roughly 0.5 percent of national spending on prescription drugs, valued at wholesale prices.) $^{130}$

- Direct spending by the federal government would decrease by $\$ 46$ million over the $2009-2013$ period, and by $\$ 5.9$ billion over the $2009-2018$ period. Federal revenues would increase by $\$ 6$ million over the 2009-2013 period and by $\$ 0.8$ billion over the 20092018 period. As a result of those changes, CBO estimates that enacting the bill would reduce budget deficits (or increase surpluses) by a total of $\$ 52$ million over the2009-2013 period and by $\$ 6.6$ billion over the 2009-2018 period.

- Implementing S. 1695 would increase federal discretionary costs, on net, by nearly $\$ 30$ million over the $2009-2013$ period and by $\$ 5.3$ billion over the 2009-2018 period, assuming appropriation of the necessary amounts, mostly because the bill would authorize discretionary spending equal to the estimated amount of savings to the federal government under the legislation. These sums exclude FDA's costs to administer the new regulatory program established under the bill. ${ }^{132}$

The bill would also significantly decrease Medicaid expenditures. "CBO estimates that state spending for Medicaid would decrease by about $\$ 4$ billion over the 2009-2013 period."133

BIO is a proponent of the Pathway for Biosimilars Act (H.R. 5629), introduced in March of 2008 by Reps. Anna Eshoo (D, Calif.) and Joe Barton ( $R$, Texas). ${ }^{134}$ This bill would provide innovators twelve years of exclusivity, and a possible two-year extension if a newly approved use of the drug is discovered. ${ }^{135}$ BIO contends that fourteen years of exclusivity is

130. CBO Cost ESTIMATE, supra note 127, at 1.

131. Id.

132. Id. at 2 .

133. Id. at 10 .

134. Doug Trapp, Disagreements Slow Progress on Biogenerics Legislation, American Medical News, Aug. 11, 2008, http://www.ama-assn.org/amednews/2008/08/11/gvsa0811. htm (last visited Mar. 6, 2010).

135. Id. 
necessary to maintain the requisite incentives to research and develop new biologics. ${ }^{136}$ The Generic Pharmaceutical Association ("GPhA") opposes the Pathway for Biosimilars Act. ${ }^{137}$ GPhA spokeswoman Andrea Hofelich stated that this legislation is "will needlessly delay affordable lifesaving biogenerics form getting to [patients]." 138 The most important of these roadblocks is the potential of fourteen years of exclusivity. ${ }^{139}$ This lengthy monopoly protection is in stark contrast to the five years of exclusivity chemical drugs are afforded under Hatch-Waxman. ${ }^{140}$

"The Eshoo-Barton legislation has been endorsed by the Pharmaceutical Research and Manufacturers of America and the [Association] of American Universities." ${ }^{141}$ The GPhA prefers the Promoting Innovation and Access to Life-Saving Medicine Act, sponsored by Representative Henry Waxman. ${ }^{142}$ This bill is very similar to the Hatch-Waxman Act, and would require similar steps to be taken for biogeneric approval as would be taken for chemical generic drug approval. ${ }^{143}$ Proponents of the Promoting Innovation and Access to Life-Saving Medicine Act cite a 2007 study by Duke University economist Henry Grabowski which concluded that the average time to develop a new biologic was 97.7 months, while the development of new chemical drugs averaged 90.3 months. ${ }^{144} \mathrm{GPhA}$ asserts that this is not a significantly different timetable, and that regulation of follow-on biologics should closely mirror that of chemical generic drugs. ${ }^{145}$

\section{F. Shorter Exclusivity Periods May Actually Promote Innovation.}

A recent study by Dr. Laurence J. Kotlikoff, Professor of Economics at Boston University, suggests that length exclusivity projections for manufacturers of biologics not only results in these drugs' high price, but also

136. Letter from John Taylor, supra note 7.

137. Press Release, The Generic Pharmaceutical Association, GPhA Says New Study Shows that Hatch-Waxman is a Successful Model for Biogenerics Legislation Exclusivity Provisions Similar to Those in Hatch-Waxman Would Promote Competition and Innovation (September 17, 2008), available at http://www.gphaonline.org/media/press-releases/2009/02/12/gpha-says-newstudy-shows-hatch-waxman-successful-model-biogenerics- (last visited Mar. 7, 2010) [hereinafter "GPhA Press Release II"].

138. Id.

139. H.R. 5629, $\$ 7(\mathrm{~A})$.

140. Drug Price Competition and Patent Term Restoration Act, Pub. L. No. 98-417 (1984), 98 Stat. 1585 (1984).

141. Trapp, supra note 134.

142. Id.

143. See Promoting Innovation and Access to Life-Saving Medicine Act, H.R. 1427, 111th Cong. (2009). This piece of legislation was first introduced on March 11, 2007 and was entitled the Access to Life-Saving Medicine Act. It was later modified to its current form.

144. Henry Grabowski, Follow-On Biologics: Data Exclusivity and the Balance Between Innovation and Competition, 7 NATURE REVIEWS: DRUG DISCOVERY 479, 481 (2008).

145. GPhA Press Release II, supra note 137. 
actually stifles innovation:

Four bills pending in Congress propose to do for biologic medications what the 1984 landmark HatchWaxman bill did for chemical medications, namely, promote a competitive marketplace that would dramatically lower prices while also ensuring strong incentives to innovate. Yet three of the four bills contain exclusivity provisions that run the danger of overextending monopoly protection. Doing so would, paradoxically, undermine innovation and the bills' own objectives. Bestowing lengthy monopolies by statute on brand biologic companies not only greatly delays entry by competitors with low-cost alternatives, but also excludes other innovators from building - in a timely manner - on the stock of prior knowledge - much of which was accumulated at public expense. ${ }^{146}$

This study represents a favorable viewpoint for generic manufacturers. While it is readily apparent that lengthy exclusivity periods allow manufacturers' to charge higher prices, the observation that these monopolies may actually inhibit innovation is much less obvious. ${ }^{147}$ Dr. Kotlikoff contends that "competition, not protection, is the true source of innovation and that overextending monopoly protection can be counterproductive." "Th "This is particularly true given the potential to use exclusivity periods to 'evergreen' one's products - to secure additional long periods of monopoly based on minor product modifications.",149

Dr. Kotlikoff cites the success of the Hatch-Waxman Act in balancing innovation with affordability, as well as the "absence of any material differences between the biologics and chemical medical industries arguing for longer monopoly protection," when recommending that Congress "consider the Hatch-Waxman model for exclusivity rather than proposals that would distort the market and undercut innovation."150

\section{The Generic Pharmaceutical Association's Response to the Kotlikoff Study:}

GPhA endorsed the findings of Dr. Kotlikoff's study in a September

146. Kotlikoff, supra note 28 , at 1 .

147. $I d$.

148. Id.

149. $I d$.

150. $I d$. 
17, 2008 press release. ${ }^{151}$ Kathleen Jaeger, President and CEO of GPhA stated:

Dr. Kotlikoff's economic analysis strongly supports the value of biogeneric competition. First, creating an approval pathway for biogeneric competition will create substantial savings for struggling consumers, and a challenged economy. Our nation needs to deliver these savings today, for those who need, but cannot afford expensive biologic medicines .... Second, balancing brand exclusivity and rewarding innovation, while permitting generic competition, is simply good medicine for our healthcare system. For nearly 25 years, Hatch-Waxman has demonstrated that when competition for pharmaceutical products exists from generics, the marketplace incentive to create new products with exclusivity spurs innovation. Dr. Kotlikoff's study notes that 'research and development in pharmaceuticals, measured relative to sales, increased dramatically after 1984' and further notes that 'NCE approvals increased by one-third in the decade following the bill's (Hatch-Waxman) passage.' These statistics clearly show that competition is good for innovation.... Third, excessive market exclusivity or the ability to evergreen products poses a significant risk to innovation. Dr. Kotlikoff's study states that 'over-extending monopoly protection... may do little or nothing to incentivize new discovery and simply delay when the next discovery comes on board.' GPhA believes that a vibrant biopharmaceutical industry, with the incentive to create new medicines, is pro-consumer and pro-healthcare. Without the incentive that competition from generics will create to develop new and more innovative products, patients suffer. $^{152}$

GPhA strongly supports Dr. Kotlikoff's conclusion that excessive exclusivity 'reduces the pace of innovation', and that exclusivity provisions similar to those applied to chemical drugs through the Hatch-Waxman Act, provide sufficient incentive to innovate while encouraging competition. ${ }^{153}$

151. GPhA Press Release II, supra note 137.

152. Id.

153. Id. 
GPhA contends that excessive exclusivity results in harm to the consumer by limiting access to affordable biogenerics and by decreasing the likelihood of new innovator products being introduced due to increased competition. ${ }^{154}$ GPhA notes the growing support for biogenerics legislation, stating that "[n]early 70 organizations representing tens of millions of Americans, including AARP, major corporations like GM and Caterpillar, the Consumer Federation of America, the AFL-CIO and more than 20 state Governors support the creation of a pathway for biogenerics." 155

In a press release, BIO argues that an approval pathway for follow-on biologics should include a fourteen year period of data exclusivity to encourage investment in biopharmaceuticals and promote the development of new therapies. ${ }^{156}$ Biologics research and development entails higher costs, longer development times, and lower late-stage success rates than smallmolecule drugs. ${ }^{157}$ The majority of biopharmaceutical companies are small startups, and an appropriate period of data exclusivity would encourage the venture-capital investment that these companies need, according to the statement. $^{158}$

\title{
III. ANALYSIS: MODIFIED VERSION OF HATCH-WAXMAN APPLICABLE TO BIOLOGICS
}

\section{A. Downfalls of proposed biogenerics bills}

\begin{abstract}
Remarkably, the Kennedy, Eshoo-Barton, and Inslee bills reward delay in getting to market with longer monopoly protection, with each year of delay beyond twelve leading to roughly one more year of protection. One wonders why legislators would want to encourage delay in the pace at which innovative drugs are brought to market and lower the speed at which today's innovations are incorporated in tomorrow's discoveries. $^{159}$
\end{abstract}

Conversely, the Hatch-Waxman and Waxman biologics bills discourage "delays in reaching the market by reducing monopoly protection by roughly one year for each year of delay.",160

Proponents of increased monopoly protection for biologics compared

154. Id.

155. Id.

156. BIO Press Release I, supra note 29.

157. BIO Press Release II, supra note 53.

158. BIO Press Release III, supra note 55.

159. Kotlikoff, supra note 28 , at 8.

160. Id. 
to chemical drugs contend that the longer time necessary for development of biologics justifies extended protection. ${ }^{161}$ While this argument has some merit, the increase in monopoly protection of biologics over chemical drugs should closely correlate to the difference in time it takes to develop biologics than chemical drug development. Biologics take on average 7.4 months longer to develop than chemical entities. ${ }^{162}$ The Eshoo-Barton and Inslee bills go well beyond compensating for this increased development time, providing innovators between 12 months and 120 months of extra monopoly protection - the variance is based on when the biologic is brought to market. $^{163}$

\section{Cost/risk justification argument}

The costs associated with introducing a new biologic into the market total an estimated $\$ 1.24$ billion. ${ }^{164}$ While this figure is staggering by any standard, it cannot be looked at alone. The cost must be put into appropriate context and should be compared to the potential return on the investment. "Invention $\mathrm{X}$ may cost $\$ 1$ million to bring to market and invention $\mathrm{Y}$ $\$ 1$ billion, but the projected revenues for $\mathrm{Y}$ may exceed those for $\mathrm{X}$ by far more than a factor of 1,000 . In this case, less monopoly protection is needed to promote invention of $Y$ than of $X . " 165$

\section{B. The Hatch-Waxman Act Should be Used as a Template for Generic Bi- ologics Legislation.}

Opponents of generic biologics contend that allowing generic production of these drugs will stifle innovation. ${ }^{166}$ The Hatch-Waxman Act is proof that generics do not stifle innovation, in fact they stimulate innovation. ${ }^{167}$

Hatch-Waxman's success did not come at the price of innovation. On the contrary, the legislation appears to have accelerated innovation.... Research and development in pharmaceuticals, measured relative to sales, increased dramatically in the years after 1984.

161. Letter from John Taylor, supra note 7.

162. Grabowski, supra note 144 , at 481.

163. S. 1695, supra note 122; H.R. 5629, supra note 126.

164. See Kotlikoff, supra note 28 , at 8 (citing Joseph A. DiMasi, Ronald W. Hansen, and Henry G. Grabowski, The Price of Innovation: New Estimates of Drug Development Costs, 22 J. HEALTH ECON. 151, 151-185 (2003)); Grabowski, supra note 144, at 482.

165. Kotlikoff, supra note 28 , at 9.

166. Letter from John Taylor, supra note 7.

167. Drug Price Competition and Patent Term Restoration Act, Pub. L. No. 98-417 (1984), 98 Stat. 1585 (1984). 
$\mathrm{R} \& \mathrm{D}$ is now running between 16 percent and 18 percent of sales, on an annual basis, compared with 8-10 percent of sales prior to Hatch-Waxman.

\section{***}

[T]he number of new drug patents issued by the U.S. Patent Office rose dramatically after 1984 and, indeed, has exceeded the pre-1984 levels in each year since the Act was promulgated. ${ }^{168}$

Any reduction in profitability of developing new drugs as a result of HatchWaxman was mitigated by other factors, including an increased reliance on medication in health care, increased demand resulting from an aging society, and an increased international demand as a result of greater parity amongst industrial nations. "For all drugs, on average, the increase in generic sales since 1984 has probably not reduced expected returns below the average capitalized costs of R\&D. On the margin, however, it is possible that a few drugs that were barely profitable to develop before may no longer be so now." 169 While generic drugs comprise a large portion of all prescriptions filled in the U.S.; the brand companies' annual revenue, over a quarter of a trillion dollars in $2007,{ }^{170}$ represents eighty-four percent of all pharmaceutical revenue. ${ }^{171}$

\section{Congress Should Assess the Arguments From These Two Inherently Bi- ased Groups With a Focus on our Country's Biotech Consumers}

This debate centers around the feasibility of safe and effective duplication of biologics, and the effect that an abbreviated regulatory pathway for follow-on biologics will have on innovation. Congress and FDA should assess these areas of contention impartially, and take action commensurate with the urgency of this highly important issue. The threshold question should be whether biologics are amenable to safe duplication. ${ }^{172}$ If they are, then follow-on biologics legislation should be enacted which strikes a balance between the necessary encouragement of innovation, and eventual relief to patients' pocketbooks.

168. Kotlikoff, supra note 28 , at 10.

169. Kotlikoff, supra note 28, at 11(quoting CONGRESSIONAL BUDGET OFFICE, STUDY: How INCREASED COMPETITION FROM GENERIC DRUGS HAS AFFECTED PRICES AND RETURNS IN THE PHARMACEUTICAL INDUSTRY (1998)).

170. Generic Pharmaceutical Association, Facts at a Glance, http://www.gphaonline. org/about-gpha/about-generics/facts (last visited Mar. 11, 2010).

171. IMS Health, "IMS National Prescription Audit Plus, National Sales Perspectives," December 2007.

172. GPhA Press Release II, supra note 137. 
An independent research panel should be used to assess the true exclusivity period necessary for biotech companies to turn a profit on a given drug. This data should be compared to corresponding data pertaining to chemical drugs, and a bill similar to the Hatch-Waxman act should be constructed which reflects any differences in the data. While a biologic may be more expensive to produce, there is no reason why Congress should be precluded from constructing a modified version of the Hatch-Waxman Act, provided generic companies prove that they are capable of safely reproducing these drugs. ${ }^{173}$

President Barack Obama has stated that he will seek to establish a regulatory pathway for generic biologic drugs as part of his Health care reform plan. ${ }^{174}$ In his budget report for fiscal year 2010, President Obama acknowledges that "[p]rescription drug costs are high and rising, causing too many Americans to skip doses, split pills, or not take needed medication altogether."175 In an effort to expand access to affordable biologic drugs, the Administration plans to establish "a workable regulatory, scientific, and legal pathway for generic versions of biologic drugs."176 Though few details are provided, President Obama's Budget Report states that the Administration will retain the necessary incentives for innovation by providing "a period of exclusivity ... generally consistent with the principles in the Hatch-Waxman law for traditional products." ${ }^{177}$ The Administration also addressed the problem of ever-greening, stating that brand biologic manufacturers will be "prohibited from reformulating existing products into new products to restart the exclusivity process." $" 178$

It is encouraging that the Obama Administration plans on addressing the problem posed by the high cost of biologics, but the contentious debate over what type of legislation is most appropriate will continue until a responsible compromise is met. The Administration's plan to allow for exclusivity of biologics "generally consistent with the...Hatch-Waxman [Act] ${ }^{179}$ may be too ambitious when considering the arguably compelling points of biologics manufacturers that the greater complexity of biologics, and the more substantial investment necessary to bring such drugs to market necessitates a longer period of exclusivity. If responsible biologics legislation is given appropriate attention in Congress, then a healthy compromise is realistic. Using the Hatch-Waxman model as a template, appropriate concessions should be made to account for the increased complexity and

173. Office of Mgmt. And Budget, Executive Office of the President, A New Era OF RESPONSIBILITY: RENEWING AMERICA's PROMISE 28 (2009) [hereinafter “A NEW ERA”].

174. Id.

175. Id.

176. $I d$.

177. Id.

178. A NEW ERA, supra note 174, at 28.

179. Id. 
expense involved in bringing a biologic to market.

\section{Biogeneric legislation as a catalyst for innovation.}

Creative destruction is a term used to refer to the cycle of innovation which is made possible by each innovation building on a prior innovation. ${ }^{180}$

Economic progress, in capitalist society, means turmoil. [What counts is] competition from the new commodity, the new technology, the new source of supply, the new type of organization ... competition which ... strikes not at the margins of the profits and the outputs of the existing firms, but at their foundations and their very lives. ${ }^{181}$

[E]ach innovation is part of a chain. Today's innovation cannot proceed if yesterday's is not accessible. And tomorrow's innovation must wait until today's innovation is available for use. Moreover, if the current length of monopoly protection suffices to incentivize today's innovation, extending the length of protection will do nothing to increase current innovation with the economy, over time, falling further and further behind with respect to the level of technology it would otherwise have available. ${ }^{182}$

\section{E. Economic/Welfare implications}

Cost savings can be achieved by biogenerics industry. In fact, "[r]ecent research suggests such an industry would save the American public at least $\$ 25$ billion and as much as $\$ 108$ billion over the next decade and greater sums thereafter from biogenerics legislation that properly limits the duration of monopoly protection."

180. Kotlikoff, supra note 28, at 14 (citing JOSEPH A. SCHUMPETER, CAPITALISM, SOCIALISM, AND DEMOCRACY (Harper \& Row 3d ed. 1950) (1942)).

181. Id.

182. Kotlikoff, supra note 28 , at 14 .

183. Id. at $12-13$ (Teva USA Government Affairs 2008) (citing CONGRESSIONAL Budget OfFICE, Cost Estimate: S. 1695 - BIOLOGICS PRICE CoMPETITION AND INNOVATION ACT OF 2007 (2008) and RoBERT J. SHAPIRO, THE POTENTIAL AMERICAN MARKET FOR Generic Biological TREatments AND tHe Associated Cost SAVINGS (February 2008)). 
reported that

[h] ealth insurance companies are rapidly adopting a new pricing system for very expensive drugs, asking patients to pay hundreds and even thousands of dollars for prescriptions [and] medications that may save their lives or slow the progress of serious diseases ... [ $\mathrm{t}$ ] he system means that the burden of expensive health care can now affect insured people, too. ${ }^{184}$

\section{F. Exclusivity Provisions should allow for abbreviated periods of monopoly protection.}

Competition, not protection, is the best tool to drive innovation. ${ }^{185}$ As Dr. Kotlikoff asserted in his assessment of how to best promote biologics innovation, "the new drugs of today are not those of tomorrow ... inventors have strong incentives to protect their discoveries, not to make new ones whose arrival on the market would undermine their existing profits." 186 While longer periods of monopoly will allow innovators to turn a greater profit per innovation, this longevity of profitability of one discovery may actually delay subsequent discoveries. ${ }^{187}$ The delay of discoveries, or at least the revelation of these discoveries, results in less total life-saving discoveries over time. ${ }^{188}$

Effective legislation will seek to minimize evergreening, particularly provisions which allow innovators to make objectively arbitrary modifications to drugs in order to maintain their monopoly. If it takes considerably longer to obtain FDA approval of generic biologics than obtaining FDA approval of chemical drugs, brand name companies will already be provided with effective exclusivity, even if this exclusivity is not provided by statute 189

The Obama Administration will likely serve as a catalyst for enactment of this legislation. ${ }^{190}$ Even though pressure continues to mount to pass biogeneric legislation, it appears likely that the public will have to wait until the next administration is in office. The thirty percent savings that would be gained has significant implications for insurance companies and

184. Kolata, supra note 42 (emphasis added).

185. Kotlikoff, supra note 28, at 15.

186. $I d$ at 16.

187. Id.

188. Grabowski and Vernon, supra note 111, at 116.

189. Id. at 104 .

190. See Julie A. Birkofer, Barack Obama's Presidential Win Denotes Big Change for the U.S., 2008 THE SOURCE 16, 16-18, available at http://www.pptaglobal.org/UserFiles/ File/Source\%20magazine/Obama_Winter\%2008.pdf (last visited Mar. 10, 2010). 
Medicare. ${ }^{191}$ Any issue affecting health insurance and Medicare will play a role in the inevitable modification of our health care system.

\section{CONCLUSION}

The brand name pharmaceutical companies' case against the introduction of biogenerics, or for lengthy exclusivity provisions, do not comport with the best interests of our Nation's economy and public health. Appropriate measures to protect innovators' investment will be an essential part of any follow-on biologics legislation, but excessive exclusivity will stifle innovation and harm consumers unable to afford costly biologics. The HatchWaxman Act's success in the regulation of generic chemical drugs indicates that similar legislation should be applied to biogenerics. The HatchWaxman Act should be used as a template to craft biogeneric legislation, which will provide much needed relief to those in need of these expensive, life-saving drugs.

191. Id. 